\title{
KARAKTERISTIK BAHASA ARAB
}

\author{
Angga Pandapotan Nasution \\ Sekolah Tinggi Agama Islam Negeri (STAIN) Sorong, Papua Barat, Indonesia \\ Jurusan Dakwah Program Studi Komunikasi Penyiaran Islam \\ Email : angganasution090@gmail.com
}

\begin{abstract}
ABSTRAK
Bahasa Arab adalah bahasa komunikasi yang dikenal erat hubungannya dengan agama islam. Kedatangan islam sebagai ajaran agama disuatu lingkungan masyarakat yang kemudian dianut sebagai pedoman hidupnya menuntu para pemeluknya untuk memahami bahasa Arab yang merupakan bahasa kitab suci ajaran islam yaitu Al-Qur'an dan Al-Hadist Nabi Muhammad SAW. pengetahuan tentang karakteristik bahasa Arab merupakan tuntunan yang harus dipahami oleh para pengajar bahasa Arab, karena pemahaman akan diskursus ini akan memudahkan mereka yang berkecimpung pada bidang pendidikan dan pengajaran bahasa Arab dalam melaksanakan kegiatan proses pembelajaran. Tetapi perlu diperhatikan bahwa karakteristik bahasa Arab tidaklah identik dengan kesulitannya, setidaknya akan tersingkap kelebihan-kelebihan yang ada pada tubuh bahasa Arab, dan menjadi aspek kemudahan yang menjadi pintu untuk membuka jalan bagi mereka yang ingin mempelajari dan mendalaminya. Bahasa Arab memiliki karakteristik yang unik dan universal. Dikatakan unik karena bahasa Arab memiliki cirri khas yang membedakannya dengan bahasa lainnya, sedangkan universal berarti adanya kesamaan nilai antara bahasa Arab dengan bahasa lainnya.
\end{abstract}

\section{PENDAHULUAN}

Bahasa Arab merupakan salah satu bahasa ilmu pengetahuan yang telah melahirkan karya-karya besar dalam berbagai bidang diantarannya, ilmu pengetahuan, filsafat, sejarah, sastra dan lain-lain. bahkan lebih dari itu bahasa Arab dapat dianggap pula sebagai peletak dasar bagi pertumbuhan ilmu pengetahuan modern yang berkembang cepat pada saat ini. Disamping itu bahasa Arab juga sebagai penerus filsafat dan kebudayaan Yunani kedunia Barat dan sebagai bahasa yang dipakai dalam hubungan internasional yang kedudukannya lebih dimantapkan setelah dinyatakan sebagai bahasa resmi dalam kegiatan Perserikatan Bangsa-Bangsa.

Dalam sejarah perkembangan ilmu pengetahuan di dunia, bahasa Arab telah memberikan sumbangan besar dan memegang peranan penting. Dikala dunia Barat pada zaman abad pertengahan masih diliputi suasana kegelapan, disaat itu ilmu pengetahuan dan 
filsafat Yunani telah disimpan dalam bahasa Arab dalam bentuk terjemahan, sehingga karena hampir semua buku-buku ilmu pengetahuan yang kenamaan diwaktu itu telah diterjemahkan ke dalam bahasa Arab, maka bahasa Arab dalam dunia keilmuan dikenal sebagai bahasa ilmu pengetahuan. Pada masa kebangkitan (Renaissance) di Barat, bahasa Arab ini berperan sebagai penghubung antara Yunani Kuno dengan Eropa modern dengan jalan menterjemahkan kembali buku-buku ilmu pengetahuan dari bahasa Arab kedalam bahasa bangsa-bangsa Barat.

Oleh sebab itu dalam hal ini penulis akan menjelaskan mengenai eksistensi dan karakterisrik bahasa Arab baik sebagai bahasa agama, maupun bahasa ilmu pengetahuan. Memahami Al Qur'an, Al Hadits, kitab-kitab Tafsir, Fiqih, Ilmu Kalam, Tasawuf dan cabang-cabang pengetahuan agama Islam yang lain mutlak memerlukan penguasaan bahasa Arab, bahkan peribadatan di dalam Islam pun sepenuhnya dilakukan dalam bahasa Arab, sehingga dengan demikian bahasa Arab sebagai bahasa yang menjadi kebutuhan utama setiap muslim.

\section{Pembelajaran Bahasa Arab}

Bahasa merupakan alat komunikasi yang digunakan untuk berinteraksi dengan sesamanya dan digunakan untuk mengeluarkan ide-ide yang ada dalam fikiran baik diucapkan melalui ucapan maupun tulisan.

Dalam berkomunikasi, seseorang tidak cukup hanya menggunakan satu bahasa saja. Akan tetapi seseorang juga perlu menguasai bahasa lain, selain bahasanya sendiri, agar terjadi komunikasi yang saling mengerti satu sama lain. Hal ini secara tidak langsung menuntut seseorang untuk belajar bahasa lain atau bahasa asing. Salah satu bahasa asing yang perlu dipelajari oleh peserta didik di Madrasah adalah bahasa Arab.

Pada umumnya motivasi dan dorongan mempelajari Bahasa Arab di Indonesia adalah untuk tujuan agama, yaitu untuk mengkaji dan memperdalam ajaran islam dari sumber-sumber yang berbahasa Arab, seperti al-Quran, al-Hadits, kitab-kitab turats dan lain-lain. Akan tetapi pada saat ini bahasa Arab telah menjadi suatu bagian dari mata pelajaran yang harus diajarkan di lembaga pendidikan formal. Terlebih lagi di lembaga pendidikan Islam, bahasa Arab merupakan suatu keharusan untuk diajarkan kepada peserta 
didik. Secara toritis, paling tidak ada empat orientasi pendidikan bahasa Arab sebagai berikut:

a. Belajar bahasa Arab untuk tujuan memahami dan memahamkan ajaran Islam. Orientasi ini dapat berupa belajar keterampilan pasif (mendengar dan membaca), dan dapat pula mempelajari keterampilan aktif (berbicara dan menulis).

b. Belajar bahasa Arab untuk tujuan memahami ilmu-ilmu dan keterampilan berbahasa Arab. Orientasi ini cenderung menempatkan bahasa Arab sebagai disiplin ilmu atau obyek studi yang harus dikuasai secara akademik.

c. Belajar bahasa untuk kepentingan profesi, praktis atau pragmatis, seperti mampu berkomunikasi lisan dalam bahas Arab untuk bisa menjadi TKI, diplomat, turis, misi dagang, atau untuk melanjutkan studi di salah satu negara Timur Tengah, dan sebagainya.

d. Belajar bahasa Arab untuk memahami dan menggunakan bahasa Arab sebagai media bagi kepentingan orientalisme, kapitalisme, imperalisme, dan sebagainya.

Adapun ruang lingkup pembelajaran bahasa Arab melputi; unsure unsur kebahasaan, terdiri atas tata bahasa (qawaidu al-lughah), kosakata (mufradat), pelafalan dan ejaan (ashwat Arabiyah), keterampilan berbahasa, yaitu menyimak (istima'), berbicara (kalam), membaca (qira'ah), dan menulis (kitabah), dan aspek budaya yang terkandung dalam teks lisan dan tulisan.

\section{Karakteristik Bahasa Arab}

Pada dasarnya, setiap bahasa merupakan alat komunikasi. Setiap komunikasi tentunya menuntut adanya kesepahaman oleh sesama pelaku komunikasi. Namun di sisi lain, setiap bahasa memiliki karakteristik tersendiri yang membedakannya dengan bahasa Arab. Demikian halnya dengan bahasa Arab. Bahasa Arab memiliki sejumlah karakteristik yang membedakannya dengan bahasa lain. Berikut ini merupakan beberapa karakteristik yang sekaligus menjadi pembeda bahasa Arab dengan bahasa lainnya.

a. Bahasa Arab berbeda dengan bahasa Indonesia. Dalam bahasa Arab terdapat pembedaan jenis laki-laki dan perempuan (mudzakar-muannats) atau tunggal (mufrad), dual (mutsanna) dan plural (jama'). Sedangkan dalam bahasa Indonesia hal tersebut tidak dikaidahkan dalam struktur kalimat. Namun bagi orang Arab, 
pengucapan bunyi konsonan /ng/, /ny/,/c/, /p/, /g/, serta vokal /o/, /ỏ/, /e/, /ẽ/, juga dinilai sangat sulit karena mereka tidak mempunyai konsonan dan vokal itu. Akan tetapi dalam banyak kasus, struktur dan gaya bahasa Arab cenderung lebih variatif, indah dan sarat makna dibandingkan dengan bahasa lainnya.

b. Struktur kalimat deklaratif bahasa Arab tidak memerlukan adanya kata sarana yang menjelaskan hubungan antara subjek dan predikat. Bahasa Arab senantiasa memiliki asumsi bahwa keberadaan gagasan di dalam benak lebih penting dan lebih benar daripada gagasan itu dalam dunia nyata.

c. I'rab, sesuatu yang mewajibkan keberadaan akhir kata pada keadaan tertentu, baik rofa', nashab, jazm dan jar yang terdapat pada isim (kata benda) dan juga fi'il (kata kerja).

d. Kata kerja dan gramatikal yang digunakan selalu berubah sesuai dengan subyek yang berhubungan dengan kata kerja tersebut.20

e. Bahasa 'ammiyah dan fush-ha, 'ammiyah dipergunakan dalam interaksi jual beli atau komunikasi dalam situasi tidak formal sedang fush-haadalah bahasa sastra dan pembelajaran, bahasa resmi yang dipergunakan dalam buku keislaman dan ilmu pengetahuan.

f. Bahasa Arab sangat mementingkan unsur makna. Apapun kata atau kalimat yang diungkapkan intinya adalah penutur atau penulis dapat memberikan makna secara utuh, dan pendengar atau pembaca dapat menangkap makna ini secara utuh pula.

g. Integrasi dua kata, yakni dua kata yang memiliki makna berbeda, lalu diungkapkan dalam kata yang menunjukkan dua (mutsanna) secara morfologis dan telah menjadi istilah baku dalam bahasa Arab.

h. Adanya tashrif, yaitu perubahan bentukan kata tertentu ke dalam bentukanbentukan lain berdasarkan pola-pola yang sudah baku.

\section{KESIMPULAN}

1. Bahasa merupakan alat komunikasi yang digunakan untuk berinteraksi dengan sesamanya dan digunakan untuk mengeluarkan ide-ide yang ada dalam fikiran baik diucapkan melalui ucapan maupun tulisan. ada empat orientasi pendidikan bahasa Arab sebagai berikut:

a. Belajar bahasa Arab untuk tujuan memahami dan memahamkan ajaran Islam. 
b. Belajar bahasa Arab untuk tujuan memahami ilmu-ilmu dan keterampilan berbahasa Arab.

c. Belajar bahasa untuk kepentingan profesi, praktis atau pragmatis, seperti mampu berkomunikasi lisan dalam bahas Arab.

d. Belajar bahasa Arab untuk memahami dan menggunakan bahasa Arab sebagai media bagi kepentingan orientalisme, kapitalisme, imperalisme, dan sebagainya.

2. Pada dasarnya, setiap bahasa merupakan alat komunikasi. Setiap komunikasi tentunya menuntut adanya kesepahaman oleh sesama pelaku komunikasi. Berikut ini merupakan beberapa karakteristik yang sekaligus menjadi pembeda bahasa Arab dengan bahasa lainnya.

a. Bahasa Arab berbeda dengan bahasa Indonesia. Dalam bahasa Arab terdapat pembedaan jenis laki-laki dan perempuan (mudzakar-muannats) atau tunggal (mufrad), dual (mutsanna) dan plural (jama'). Sedangkan dalam bahasa Indonesia hal tersebut tidak dikaidahkan dalam struktur kalimat.

b. Struktur kalimat deklaratif bahasa Arab tidak memerlukan adanya kata sarana yang menjelaskan hubungan antara subjek dan predikat.

c. I'rab, sesuatu yang mewajibkan keberadaan akhir kata pada keadaan tertentu, baik rofa', nashab, jazm dan jar yang terdapat pada isim (kata benda) dan juga fi'il (kata kerja).

d. Kata kerja dan gramatikal yang digunakan selalu berubah sesuai dengan subyek yang berhubungan dengan kata kerja tersebut.

e. Bahasa 'ammiyah dan fush-ha, 'ammiyah dipergunakan dalam interaksi jual beli atau komunikasi dalam situasi tidak formal sedang fush-haadalah bahasa sastra dan pembelajaran, bahasa resmi yang dipergunakan dalam buku keislaman dan ilmu pengetahuan.

f. Bahasa Arab sangat mementingkan unsur makna. Apapun kata atau kalimat yang diungkapkan intinya adalah penutur atau penulis dapat memberikan makna secara utuh, dan pendengar atau pembaca dapat menangkap makna ini secara utuh pula.

g. Integrasi dua kata, yakni dua kata yang memiliki makna berbeda, lalu diungkapkan dalam kata yang menunjukkan dua (mutsanna) secara morfologis dan telah menjadi istilah baku dalam bahasa Arab.

h. Adanya tashrif, yaitu perubahan bentukan kata tertentu ke dalam bentukanbentukan lain berdasarkan pola-pola yang sudah baku. 


\section{DAFTAR PUSTAKA}

Bisri, M. dan Abdul, H. (2012). Metode dan Strategi Pembelajaran Bahasa Arab. Malang: UIN Maliki Press.

Abdul Hamid, dkk. (2012). Pembelajaran Bahasa Arab, Pendekatan, Metode, Strategi, Materi, dan

Media, Malang: UIN-Malang Press.

Arsyad, A. (2010). Bahasa Arab dan Metode Pengajarannya. Yogyakarta: Pustaka Pelajar. Syukron Kamil. (2012). Teori Kritik Sastra Arab: Klasik dan Modern. Jakarta: RajaGrafindo.

Amin Muhammad. (1980). al-Lughat al-“Arabiyyah Ma’nâhâ wa Mabnâhâ. Mesir: Dâr elFikr.

Ismail, \& Haryati S, Nas. (2008). Studi Bahasa Arab dan Kata Serapan Bahasa Arab dalam bahasa Indonesia. Semarang: RUMAH INDONESIA 